\title{
Trzy zwiędłe liście, trzy smutne wiersze (Garczyński, Lenartowicz, Asnyk)
}

Pisanie i czytanie wierszy o jesieni obciążone jest wspólnym, łatwo rozpoznawalnym ryzykiem utknięcia w nieznośnej kliszy. Gdy „szemrzą jesienne deszcze, / naówczas w głąb własnej duszy / Chmurni wpatrują się wieszcze" — - naigrywał się w Spowiedzi poety niestrudzony demaskator poetyckich banałów Tadeusz Żeleński (Boy). A przecież żadna ironia, parodia czy szyderstwo nie są w stanie zaprzeczyć wyjątkowej lirycznej dyspozycyjności jesieni. „Konająca natura wzywa wielbiciela swego” ${ }^{2}$ pisał Kazimierz Brodziński, potwierdzając szczególną poręczność tej pory roku w twórczości elegijnej. Autor $O$ elegii precyzyjnie uzasadnia to przekonanie. Poeta znajdzie inspirację „w jesieni, kiedy natura, jak matka klejnoty między córki swoje dzieląca, wszystkie bogactwa i ozdoby rolnikom w posagu oddaje, kiedy spieszniejsze strumienie niesione pożółkłe liście piaskom nadbrzeżnym powierzają, kiedy niewdzięczne ptaki do szczęśliwszej

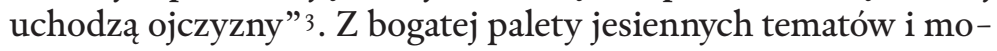
tywów wybieram jeden, wcale nie najmniej zużyty - podnoszę trzy „pożółkłe liście”, na których zapisano trzy smutne wiersze.

\section{Dziki ślad. Odpowiedźna list Stefana Garczyńskiego ${ }^{4}$}

Druga połowa roku 1832 stanowi kulminacyjny, a zarazem trudny do rozczytania epizod w kalendarzu życia i twórczości Stefana

${ }^{\text {I }}$ T. Żeleński (Boy), Spowiedź poety, w: Pisma, t. 1: Stówka, Warszawa 1956, s. 190 .

${ }^{2}$ K. Brodziński, O elegii, w: Wybór pism, oprac. A. Witkowska, Wrocław 1966, s. 350 .

3 Ibidem.

4 Wiersz Odpowiedź na list zamieszczam w aneksie. Ten oraz inne teksty poety cytuję za wydaniem: Poezye Stefana Garczyńskiego, Przemyśl 1882. 
Garczyńskiego. Zmuszony do opuszczenia ulubionego Lubostronia, a później kraju, niepogodzony z klęską powstania, osamotniony na wygnaniu (najbliższy towarzysz, Adam Mickiewicz, wyjechał z Drezna nieco wcześniej), a przede wszystkim coraz bardziej wyniszczony chorobą poeta przeżywał okres wzmożonej aktywności pisarskiej. Szykował do druku Wactawa dzieje, pisał nowe wiersze, zasypywał autora Dziadów, który podją się zrecenzowania i przeprowadzenia korekty jego poezji, drobiazgowymi poprawkami, a jednocześnie odbierał listy pełne zatroskania o swój stan zdrowia. W ten korespondencyjny odcinek biografii samotnego poety wpisuje się Odpowiedź na list, krótki liryk napisany (podobnie jak $W$ nocy jesiennej) prawdopodobnie jesienią 1832 r. 5 .

Niespokojny, „pierścieniowy” lot jesiennego liścia stanowi w tym wierszu główny obraz, od początku do końca skupiający na sobie uwagę. Zadaniem czytelnika jest podążanie w ślad za ruchliwym przewodnikiem, który - na przekór konsekwentnemu obrazowaniu, nakłaniającemu do lektury w kluczu łatwej alegorii przemijania - prowadzi do celu dość krętą drogą. Niewielkich rozmiarów utwór przedstawia złożoną sytuację liryczną, dlatego warto go porządkująco sparafrazować. Tekst można podzielić na cztery części: rzecz rozpoczyna się od pytania retorycznego o szczęście „samotnego liścia” „służącego wiatrom” (w. 1-3), następnie opisana zostaje „przypadkowa” zasada jego ruchu (w. 4-5), później wiersz przybiera postać namowy do podążania „dzikim śladem” liścia i przyglądania się mu (w. 6-9), po czym wycofuje się z tego, prosząc o pozostawienie liścia samemu sobie (w. 10-16).

Streszczenie uwypukla charakterystyczną zmienność intencji podmiotu, lecz pomija element, który na kierunek czytania ma wpływ decydujący. Jeśli konwencjonalną funkcją tytułu jest powiadomić „w mniej lub bardziej wyraźny sposób, «o co w utworze chodzi»" ${ }^{6}$, to Odpowiedź na list daje więcej niż wyraźne wskazówki. Tytuł objaśnia sytuację komunikacyjną (rozmowa na odległość), wprowadza aluzję gatunkową (list poetycki), intensyfikuje odniesienia biograficzne (korespondencja Garczyńskiego), a przede wszystkim uruchamia interpretacyjnie obiecującą wymianę znaczeń - liść jest w tym utworze figurą przynajmniej podwójną, oznacza życie i pisanie.

5 O okolicznościach powstania obu tekstów można wnioskować jedynie na podstawie poszlak: „Na to, że powstały one jesienią 1832 roku, wzkazuje tytuł pierwszego oraz wspólne motywy jesieni”. Z. Szeląg, Stefan Garczyński. Zarys biografii, Kielce 1983, s. 129.

6 D. Danek, O tytule utworu literackiego, „Pamiętnik Literacki” 1972, z. 4, s. 143. 
Autobiograficzna sugestia, charakterystyczna dla refleksyjno-elegijnej liryki Garczyńskiego ${ }^{7}$, jest widoczna. Młody poeta miał prawo, by przedstawiać się jako „sierota uniesiony ręką dzikiej burzy", był bowiem osierocony podwójnie: dorastał bez rodziców, a po klęsce powstania listopadowego musiał opuścić ojczyznę. W zachowanej częściowo korespondencji nastrój depresyjny (i zwrotnie: ton pocieszenia dla chorego i samotnego poety) powracał regularnie. W sierpniu $1832 \mathrm{r}$. poeta, mocno już pognębiony chorobą, tak odpowiadał na przyganę Stanisława Baranowskiego, towarzysza studenckiej młodości: „Słabość wszystkich Polaków, tęsknota do kraju, jest zapewne i moją słabością [...]. Każesz mi wypogodzić duszę moją. Chciałbym, gdyby można, ale zmartwienia u mnie, jak grzyby po deszczu codziennie nowe wyrastają. Źle, źle to zapewnie, ależ nie odmienić" ${ }^{8}$. Tę odpowiedź na list mogłaby z powodzeniem zastąpić $O d-$ powiedź na list. Udręka własnej choroby (,zżółkłym ci w oczach stanie, otoczony gadem, / który go wskroś przekąsił i wciąż go przekąsa”) i przeczucie rychłej śmierci („Ale wierzaj - wkrótce zginie!”) nieustannie towarzyszą poecie: „śmierć swoję często przepowiadał" - relacjonował już post mortem Adam Mickiewicz w liście do Antoniego Edwarda Odyńca. Konkluzja wiersza, odczytywanego $\mathrm{w}$ tej perspektywie, ma wydźwięk samotniczy i separatystyczny, przypomina zakończenie Żeglarza: „pozostaw jesieni listek pożółciały”, „daj mu płynąć” odbija echem dawniejsze „wy idźcie do domu - ja płynę dalej”.

Jednak Odpowiedźna list - inaczej niż Mickiewiczowski Żeglarz - utrudnia wyraźne cięcie na linii podmiot - świat, ponieważ dość niewyraźnie sytuuje „ja” liryczne. Wiersz zwraca uwagę zagadkową epistolarnością, zachęca do namysłu nad relacyjnością ról. Tytuł prowokuje pytania: Kto, komu i na co odpowiada? Jaka była treść listu, którego się domyślamy? Można sobie wyobrazić, że „ja” ukrywa się za jesienną alegorią, przeniesione w niebezpośredniość formy trzecioosobowej („daj mu płynąć” byłoby zawoalowanym „daj mi płynąć”), chociaż tekst pozwala również trwać przy nieautobiograficznym, zdystansowanym „ja” refleksyjnym, dającym uniwersalną lekcję pogodzenia się z czasem („Lata młode - dla tego pozostaw [...] listek”). Ale

7 Pisał o tym Zdzisław Szeląg: „Charakterystyczną cechą twórczości Garczyńskiego, oprócz erotyków, jest obecność w niej autobiograficznego podtekstu. Uwaga ta odnosi się szczególnie do liryk refleksyjnych. Charakterystyczny dla nich nastrój smutku przejawia się zwykle, gdy poeta konfrontuje szczęśliwą przeszłość z teraźniejszością, z oddaleniem od kraju”. Z. Szeląg, Wstęp, w: S. Garczyński, Wybór poezji, Warszawa 1985, s. 24.

${ }^{8}$ Listy Stefana Garczyńskiego, oprac. P. Mączewski, „Myśl Narodowa” 1933 , nr 35, s. 517. 
komu dedykowaną? Sporo zależy od tego, jak przeczytamy tajemniczy zwrot do adresata: „Tobie droga!”. Jest to poszlaka, która pozwala domyślać się kobiety jako autorki hipotetycznego listu, ale może to być również mobilizujące wezwanie do rozłąki, co sugeruje zapis oraz „podróżniczy” kontekst ${ }^{9}$. Umowność sytuacji, spowodowana znaczącym wybrakowaniem tekstu, pozwala się domyślać jakiejś części „ja” również w „ty” wiersza, jakby poeta, $\mathrm{z}$ zaciekawieniem przeglądając się $\mathrm{w}$ zwierciadle czasu, otrzymał list od siebie samego, tyle że młodszego.

Replika na list dość nietypowo nie odsyła jednoznacznie do niczego i nikogo poza sobą samą, roboczo spróbujmy zatem potraktować podział ról (,ja” - nadawcy, „ty” - odbiorcy, „on” - zapośredniczającej, jesiennej metafory) jako chwyt, którego głównym celem nie jest referencjalne odniesienie, lecz uczasowienie sytuacji lirycznej, umożliwiające konfrontowanie lepszego „kiedyś” ze schyłkowym „dziś”. Elegijność, jak pisze Bernadetta Kuczera-Chachulska, oznacza „zwrot ku «sobie samemu», osobowości utrwalonej przez przeszłość” " ${ }^{\circ}$. Wydaje się, że korespondencyjne odegotyzowanie tego zwrotu broni wiersz przed pokusą solipsyzmu i nihilizmu, otwiera go na „doświadczenie heteronomiczne". Emmanuel Lévinas uważa je za lek na egoistyczną „tautologię tożsamości”, który umożliwia prawdziwe poznanie, rozpoczynające się od "pobudzenia ja przez zewnętrzne ja” " Myślenie o „ja” wykraczające poza opłotki „ja” daje szansę porachowania się $\mathrm{z}$ czasem bez odwoływania się do kreacjonistycznego cudu uobecnienia przeszłości, który autorka Przemian form i postawe elegijnych... kojarzy z romantyzmem. Czy wiersz z szansy tej skorzystał?

Refleksja poety osadzona jest w podwójnym układzie metaforycznych odniesień - liścia i listu, jesieni i pisma. Nie są to, rzecz jasna, rozłączne porządki figuracji. Powstanie formy „liść” ze zbiorowego rzeczownika „liście” doprowadziło w polszczyźnie do wykształcenia się leksemów z odrębnymi paradygmatami fleksyjnymi - słowa „liść” i „list” są etymologicznie spokrewnione. Znaczenie wcześniejsze dotyczyło oczywiście organu rośliny (notujemy takie użycie leksemu „list” w XIV w.), dopiero wtórnie oznaczało „coś cienkiego, płaskiego, w kształcie liścia”,

9 Zdzisław Szeląg, opracowując wybór wierszy Garczyńskiego (por. przyp. 7), zmienia wykrzyknik (obecny we wszystkich poprzednich wydaniach) na przecinek, sugerując tym samym ścieżkę lektury.

ro B. Kuczera-Chachulska, Przemiany form i postaw elegijnych w liryce polskiej XIX wieku, Warszawa 2002, s. 310.

${ }^{\text {II }}$ E. Lévinas, Ślad innego, przeł. B. Baran, w: Filozofia dialogu, oprac. B. Baran, Kraków 1991, s. 213. 
czyli „pismo, dokument” ${ }^{\text {I2 }}$. To pokrewieństwo zachęca do poszukiwania związku między jesiennym liściem a listem $\mathrm{w}$ wierszu Garczyńskiego. Odnajdujemy go w wyobrażeniu kruchości, ulotności, mijania - czyli w pojęciu śladu. Tytuł utworu wprowadza płaszczyznęuprzedniości (list, którego wiersz jest śladem), a jednocześnie ustanawia „pakt korespondencyjny”, oparty na łączności, odpowiedniości (correspondance), umożliwiający dialog, wymianę znaczeń między liściem a listem. Myślenie elegijne pochyla się nad fenomenami jesieni, ponieważ mogą one w temporalnym języku alegorii wyrażać prawdę o „czasie, który się o nas nie troszczy" "3, jak to w żargonie heideggerowskim ujmował Paul Ricoeur. Elegia - twierdził filozof - stanowiła lekcję „uzgodnionej sprzeczności”: „poświęcona ludzkiej kondycji, przybierając na przemian postać skargi i rezygnacji, nieustannie podkreślała ów kontrast między czasem, który trwa, i nami, którzy przemijamy" I4. Z drugiej strony list, będący dokumentem, również wyraża stosunek do czasu. „Źródłem autorytetu dokumentu - pisze Ricoeur - jakim cieszy się on jako narzędzie [...] pamięci, jest znaczeniowość związana ze śladem" ${ }^{5}$. Zadaniem lektury jest zatem wyjaśnić, jaki status tekst nadaje śladowi, co w wierszu Garczyńskiego znaczy podążać „dzikim śladem" liścia.

Twórca elegijny nauczony jest szukać wokół siebie śladów utraconego czasu, rozmawia z przeszłością dzięki uznakowieniu tego, co po sobie pozostawiła. Interesuje się łupiną, pomimo iż (albo: dlatego że...) nie ma w niej już pestki. „Żałosne ubiory [...] / Po co me smutne oczy za sobą ciągniecie, / Żalu mi przydajecie?" - wersy z trenu Jana Kochanowskiego dobrze obrazują przechodniość śladu, który „znaczy poza byciem”, wskazuje na minione, choć go nie uobecnia. Odpowiedź na list rozwija się według pozornie odwróconego zamysłu, stanowi przykład liryki niemożliwej do odegrania roli - tym, co pozostawia ślad, jest starość („listek pożółciały”), a podążać za nim ma młodość, jakby ku przestrodze. Jednak poetycka replika nie zawiera spójnej argumentacji, świadczy o zmienności nastroju: „Popłyń jego śladem” - „przypatrz mu się” - „pozostaw listek pożółciały” „daj mu płynąć”. Wiersz nawiązuje łączność, by zaraz potem ją zerwać, przez co w interesujący sposób dialoguje z tradycją li-

I2 Zob. K. Długosz-Kurczabowa, Nowy stownik etymologiczny języka polskiego, Warszawa 2003, s. 280-281.

I3 P. Ricoeur, Czas i opowieść, t. 3: Czas opowiadany, przeł. U. Zbrzeźniak, Kraków 2008, s. 177.

${ }^{14}$ Ibidem.

I5 Ibidem, s. 171. 
stu poetyckiego. Popularna forma umożliwiała - pisze Elżbieta Nowicka - „rozmowę współczesnych za pomocą alfabetu tradycji”. W takiej wymianie zdań porozumieć się mogli nawet polemiści, autorzy o różnych temperamentach poetyckich (jak Teofil Lenartowicz i Cyprian Norwid): „wobec romantycznego dylematu «samotności» $\mathbf{i}$ «uczestnictwa» list poetycki plasował

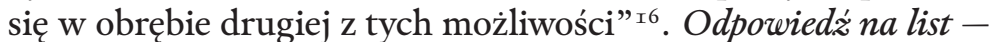
ukrywając swojego adresata, a nadawcę rozbijając na szereg ról tekstowych - dyskutuje z ideą poetyckiej rozmowy, opowiada o pokusie samotności i trudnościach z uczestnictwem.

Umiarkowany ton elegii zostaje zaburzony, gdy poeta nadaje śladowi energiczny, niemal namacalny charakter „dzikiego śladu”. W tym epitecie zawiera się podwójna niemożliwość. Liść unoszony przez wiatr nie pozostawia po sobie śladu (chociaż sam nim jest), natomiast dzikie zwierzę (lub metaforycznie: „dzika burza”) może go odcisnąć w jesiennym listowiu, nie użyczając jednak atrybutu - ślad nie jest sam w sobie dziki. Jeśli zatem ślad „wskazuje [...] na przejście, a nie na możliwą obecność” ${ }^{77}$, to „dziki ślad” sprzeciwia się temu - nie akceptując przejściowości, zabiega o zjawienie się, próbuje dokonać metonimicznej zamiany śladu na obecność („dzika burza” pozostawia po sobie znaczącą resztę, „dziki ślad”). A przecież wytworzyć „dziki ślad" jest równie trudno, jak rozzłościć własny cień, zanimizowany odcisk staje się nieoswojoną, gwaltowną metaforą niezgody na śladowość. Jej dziki charakter przedstawia się nieco odmiennie tylko $\mathrm{w}$ jednym, niezwiązanym $\mathrm{z}$ burzą znaczeniu, jako „pierwotność” (bo już nie jako „nieoswojenie” czy „gwałtowność”). Nawet taka interpretacja - wcale nie najbardziej narzucająca się - nie uwalnia jednak figury od wewnętrznego napięcia, nie pozbawia jej charakteru polemicznie prezentystycznego. Przez odwołanie do praśladu pierwotność pozostaje uwikłana w grę uobecniania, które jednak - jeśliby podążać za wykładem Jacques'a Derridy - pozostaje zawsze tylko życzeniem, ponieważ „nie istnieje źródłowy ślad” ${ }^{8}$.

${ }^{16}$ E. Nowicka, Postylion niesie pisanie... Szkice o romantycznym liście poetyckim, Poznań 1993, s. 172.

${ }^{17}$ P. Ricoeur, op.cit., s. 179.

I8 Warto przypomnieć wywód Derridy, ponieważ koresponduje on z romantycznym myśleniem na temat początku („Dziecko jest ojcem męża dojrzałego" - pisał William Wordsworth), zachęcajac do jego reinterpretacji: „Jest ono [pojęcie praśladu] w sobie sprzeczne i nie do przyjęcia w ramach logiki tożsamości. Ślad nie jest wyłącznie zniknięciem początku, oznacza on tutaj [...], że początek nawet nie zniknął, że ukonstytuowany został jedynie zwrotnie przez nie-początek, ślad, który staje się w ten sposób początkiem początku. [...] jeśli wszystko zaczyna się od śladu - przede wszystkim nie istnieje źródłowy ślad". J. Derrida, O gramatologii, przeł. B. Banasiak, Warszawa 1999, s. 94. 
Liryk Garczyńskiego odsłania janusowe oblicze. Dostrzegalnie rozszczelnia wzorzec elegii (rozumianej jako „zwrot ku sobie samemu") przez korespondencyjne rozbicie ról. Daje ono szansę przetrwania innemu („pozostaw jesieni listek”, „daj mu płynać”") w zamian za skoncentrowanie w zalegoryzowanym , ja” całej destrukcyjnej mocy śmierci. Śmiały wiersz wyobraża sobie „trwanie poza sobą” i godzi się na ocalenie młodości jedynie w formie śladu - psychicznego i poetyckiego. „To zwycięstwo w czasie beze mnie”, „bez wkraczania na ziemię obiecaną” jest mówiąc językiem Lévinasa - wynikiem "hojnego uczynku” poetyckiego, czyli samodzielnego szamotania się z "gadem”. Z drugiej strony, wiersz tematyzujący kwestię „znaczeniowości śladu" nie potrafi oprzeć się pokusie magii paralelizmu, widocznego połączenia „listka pożółciałego” z „kwiatkami nadziei” za pomocą zmaterializowanego „dzikiego śladu”.

To napięcie utrzymywało liryczną wyobraźnię Garczyńskiego w gotowości do samego końca - co widać choćby w liryku $W$ tydzień po plynieniu tódka na Lemanie, napisanym w lipcu 1833 r., a zatem krótko przed śmiercią poety. Uniwersalna figura życia jako żeglugi naznaczona jest rozpoznanym wcześniej niezdecydowaniem („I żagle rozpostarłem, pędzę przez wód piany”; „Opuszczam tedy żagle. Na brzeg pchnijmy łodzie”), a myśl osiada na mieliźnie, utyka wśród wątpliwości („Dawniej... Lecz na co przeszłe wywoływać duchy? / Życie w przeszłości - śmiercią prawdziwą w zarodzie"). Wiersz powątpiewa w sens, a może i możliwość - skoro „zaród” skażony jest śmiercią - poetyckiego „wywoływania duchów”, choć jednocześnie całkiem jawnie to robi - o czym przecież informuje już w tytule.

\section{Zimny ślad. Liście zwiędłe Teofila Lenartowicza ${ }^{19}$}

Teofil Lenartowicz, poszukiwacz „cienistych rejonów idylli”, dających schronienie przed skrajnościami niestosownej radości, ale i nadmiernego smutku ${ }^{20}$, po roku 1860 coraz głębiej wstępuje $\mathrm{w}$ strefę elegijnego cienia. Wymuszona przeprowadzka z Rzymu do Florencji powoduje, że „kontakty osobiste rwą się [...], a pod-

I9 Tekst Liści zwiędlych zamieszczam w aneksie. Ten oraz inne wiersze poety cytuję za wydaniem: T. Lenartowicz, Wybór poezyj, oprac. J. Nowakowski, Wrocław 1972.

${ }_{20}$ Zob. M. Skibińska, Stowiczy niepokój - o cienistych rejonach idylli w poezji Teofila Lenartowicza, „Literatura Ludowa” 2007, nr 1, s. 38. Jest to rozwinięcie koncepcji Lenartowiczowskiej ,idylli zranionej”. Por. M. Janion, Wiersze sieroce Lenartowicza, „Pamiętnik Literacki” 1972, z. 4. 
trzymuje jegłównie obfita i pracowita korespondencja" ${ }^{21}$, dochodzi do tego podwójna strata osobista (śmierć dopiero poślubionej żony i ledwie narodzonego synka), zacierający się w pamięci obraz Mazowsza, do którego przecież od zawsze stroiła się lira poety. Rozpoczyna się jesień, wśród której krążą listy i liście, które „wiatr nieprzyjazny roznosił po ziemi”. Cytat pochodzi z elegijnego wiersza poświęconego pamięci Ignacego Komorowskiego (towarzysza z czasów mazowieckiej młodości). Podmiot próbuje w nim przeciwstawić się złemu wiatrowi, zapowiadającemu los wygnańczy: „Żaden nas tak wicher nie rozgoni”. Paralelizm ludowy, wyćwiczony chwyt śpiewnej poetyki Lenartowicza, przez który przeświecała „idea współbrzmienia natury i człowieka, idea tajemnych między nimi correspondances" ${ }^{22}$, znajduje nowe zastosowanie w jesiennej liryce wygnańca - wraz z nim rozwija się bujna korespondencja $\mathrm{z}$ utraconymi miejscami i minionymi chwilami.

Udaną realizacją tej poetyki są Liście zwiędte, melodyjny wiersz rozmowa umierającego liścia z przechodniem. Dialog rozpisany został na cztery wersyfikacyjnie zróżnicowane kwestie. Na smutne wspomnienie i prośbę liścia odpowiada przechodzień o „duszy zwiędniałej”, po czym głos powraca do antropomorfizowanej przyrody. Ostatnia z wyróżnionych całostek wiersza, apostrofa do wiatru, mąci klarowność lirycznego dialogu - jej autorstwo pozostaje niepewne. Otwierająca tekst przemowa liścia jest interesownym spisem zasług $-\mathrm{z}$ jego cienia solidarnie korzystali zmęczony pielgrzym, bladolice dziewczę i słowik. W zamian za życie „piękne i szlachetne” podmiot (liść), który, jak czujemy, musi być synekdochiczny (powiada: „mój los”, ale „cieńmi moimi”, na mnogość wskazuje również tytuł), prosi przechodnia (który również może oznaczać wielu: „przechodniu”, ale wcześniej: „widzicie”) o uszanowanie jego snu - niedeptanie jesiennego listowia. Odpowiedź przechodnia, śpiewnie wtórując, rozsnuwa jednocześnie egzystencjalną analogię: podmiot o „duszy zwiędniałej”, „zwiany z Polski kochanej”, podrzucany „przez losu wiatr lekki” obiecuje nie deptać liścia. Tertium comparationis przenośni, zorganizowanej wokół braku cienia z jednej, a ojczyzny z drugiej strony, jest wyobrażenie utraconego schronienia. Głosy splecione w tej elegijnej paraleli układają się w sekwencję, w której wyciszony żal po stracie, ocierający się zrazu o poczucie beznadziejności, prowadzi do słabego optymizmu. „Przeznaczon jestem na gnicie” - taką

${ }^{21}$ J. Nowakowski, Wstęp, w: T. Lenartowicz, Wybór poezyj, oprac. J. Nowakowski, Wrocław 1972, s. LV.

${ }^{22}$ M. Janion, op.cit., s. 101. 
konsekwencję z korespondencji wyciąga przechodzień. $\mathrm{Za}$ to liść, któremu przypisany jest naturalny, organiczny optymizm, nie myśli, że jest ostatecznie „zgubiony”: „Jak kiedyś cienie dawałem,/ Tak dzisiaj ziemię mym ciałem/ Użyźnię...”. Wiersz proponuje zatem bynajmniej nie odkrywczą, naturalistyczną teleologię śmierci, nienachalnie sugerując przy okazji jej historiozoficzne zastosowanie - poza horyzontem tego wiersza, ale nie poza zasięgiem interpretacji, jest bowiem nadchodząca wiosna (ale i kolejna jesień).

Przejrzystość elegijnej intencji wiersza słabnie w dwóch miejscach. Pierwszym jest strofa, w której przechodzień z empatią odpowiada na prośbę liścia: „żółty biedaku, / Ja ciebie deptać nie mogę”. Przyrzeczenie to zostaje wzmocnione w ostatnich wersach apostrofy:

Więc na mej drodze

Ja cię obchodzę,

W głuchą idący dolinę;

I wszystkie bratnie

Liście ostatnie

Z ściśniętym sercem ominę.

Fragment ten wprowadza w obręb dość prawdopodobnej relacji człowieka i przyrody (gdyby pominąć uzasadnioną lirycznie antropomorfizację tej drugiej) moment prawie przesądzonej niemożliwości - postanowienie omijania wszystkich liści opadłych z drzew (lub przynajmniej z jednego drzewa) wydaje się pomysłem niedorzecznym. Łatwo nie podeptać samotnego liścia, ale i jesień, i wiersz wykonują działania na wielkich liczbach, w zadrzewionej okolicy człowiek zmuszony jest brodzić po listnym kobiercu, o żadnym niedotykaniu nie ma mowy. Im dalej w jesień, im głębiej w "głuchą dolinę” zstępuje przechodzień, tym jawniej niewiarygodne staje się jego postanowienie. Nie mniej niż obietnica przechodnia dziwi prośba liścia. Wszakże deptanie nie jest wrogie symbiotycznej teleologii wiersza: po więdnących i gnijących liściach chodzą ludzie i zwierzęta, włączając się w rytm naturalnego procesu, przemieniającego organiczne szczątki w użyźniający pokarm.

Skąd więc ostatnie życzenie listka, który godząc się ze swoim losem (więdnięcie - spadanie - gnicie - użyźnianie), jednocześnie się jemu sprzeciwia (niedeptanie)? Skąd naiwność przechodnia, składającego obietnicę, której nie będzie w stanie wypełnić? Ten wspólny protest przeciw nieuniknionemu pojmuję jako niezgodę na trudną prawdę skrytą w paralelizmie. Jesienią 
czytelny grunt zanika, ślad gubi się zasypany milionem liści, trudnych do rozróżnienia w swej masie. Unik wobec naporu liści jest unikiem wobec utrwalonej metafory przemijania i zacierania pamięci. Przeszukujemy niekiedy listowie w nadziei znalezienia czegoś twardego, na czym może zaczepić się wspomnienie. Radość z podniesionego kasztana, który łatwo zamienia się w pamiątkę, oraz pokusa utrwalenia (zasuszenia) samego liścia są ćwiczeniami z anamnesis, aktywnego oporu wobec rozmazującej kontur natury, dość precyzyjnie opisanej w jednym $\mathrm{z}$ wierszy Adama Zagajewskiego: „Jesień zrywa liście z drzew i nazwy, owoce./ Jesień zaciera ślady, granice”.

Zakończenie Zwiędlych liści jest drugim, a zarazem ostatecznym zaburzeniem toku wiersza. Pomimo zachowania formy apostroficznej utwór traci w tym miejscu przejrzystość ustanowioną przez dialog. Zjawia się trzeci adresat apostrofy, wiatr, ale jej nadawca pozostaje nieokreślony. Czy to obaj rozmówcy ten „odwiany od krzaku” i ten „zwiany z Polski” - wspólnie wzywają podmuch sprawiedliwie kształtujący paralelne biografie? Dostrzegamy, że między trzecią a czwartą częścią wiersza przebiega wyraźny front burzowy: wcześniejszy „losu wiatr lekki” ma teraz dąć i siekać. Kształt całego fragmentu zmusza do porzucenia nastroju elegijnego. Sugeruje to już wersyfikacyjna zmiana: tekst otwiera potoczysty trzynastozgłoskowiec - uważany przez Brodzińskiego za najwłaściwszą miarę dla polskiej elegii - zamyka zaś energiczny czterozgłoskowiec z rymami męskimi w wygłosie. To harde zakończenie, które śmiało wzywa burzę i zachęca do głośnego śmiechu „głuszącego płacz”, wyrywa nas z zadumy i pozwala wierszowi przekroczyć swoją poprzednią formę: „,...] elegia nie może zajmować gwałtownych uniesień; spokojnym smutkiem być tylko powinna" ${ }^{23}$. Wygłos liryku posługuje się ponadto dość ogólnikową, a przez to enigmatyczną (i zarazem nieelegijną) metaforyką. Śmiech powstający z mogiły, zwłaszcza „życia pień” odwiecznie okalany przez „miłości bluszcz”, dopasowują się do organicznej eschatologii wiersza. To zaskakująco pewne siebie pocieszenie ma wręcz posmak rewolucyjnej pogróżki, ponieważ przywołany wcześniej motyw wygnania z ojczyzny pozwala modyfikować sens paraleli tak, by prywatny wiatr losu w porywach zamieniał się w publiczny wiatr historii.

Nie mogę jednak oprzeć się wrażeniu, że radosno-miłosny finał odcina się nastrojem od reszty wiersza w sposób sztucznie wymuszony. Nie jest chyba przypadkiem, że ulotna wizja liścia

${ }^{23}$ K. Brodziński, op.cit., s. 342. 
„suchego” i „kruchego”, spadającego pod stopy przechodnia, ustępuje pola obrazowi czepliwego bluszczu - rośliny wyjątkowo odpornej, kurczowo oplatającej się wokół wszystkiego, co daje możliwość przetrwania. Wiersz chwyta się życia, rozdmuchuje je sztucznie wzmożonym wiatrem, wyrzekając się tym samym swojego poprzedniego nastroju, po czym - na przekór hałaśliwym zaklęciom - zamiera. Oba opisane fragmenty wprowadzają zamieszanie w elegijną składnię zgody. Absurdalny projekt omijania liści, dziecinne kłamstwo przeciw czasowi, nie pasuje do atmosfery częściowego (pozornego?) pogodzenia się z losem, szukania pogrobowej pociechy w możliwości „użyźnienia” i przeczucia wiosny. Wiersz jest zapisem eskalacji symbolicznych gestów - od drobnego postanowienia przechodzi do olbrzymiej obietnicy, od cichej zgody na smutek losu do prowokacyjnego, ale też ogólnikowego wyzwania.

Jesienne wiersze Garczyńskiego i Lenartowicza nie wpadają w pułapkę tematycznego banału, zakłócając zwykły przebieg refleksji opartej na paraleli między człowiekiem a naturą. Prośba o podążanie „dzikim śladem” oraz postanowienie omijania „bratnich liści” to gesty równoważne, oba wypływają z niezgody na domknięcie analogii. Poeci docierają do miejsca, w którym staje się ona nie do zniesienia, dlatego decydują się na fałszujące odkształcenie odwiecznej paraleli, zapewniając przy okazji lirykom artystyczną autonomię. Jednocześnie żaden $\mathrm{z}$ tych tekstów nie dowierza chyba swoim poetyckim kłamstwom. W Odporeie$d z i$ na list podmiot popada $\mathrm{w}$ rezygnację i przeczucie śmierci, $\mathrm{w}$ Zwiędlych liściach - odwrotnie, niespodziewanie pojawia się ton buńczuczny, któremu towarzyszy nadzieja przetrwania. Poetyckie próby wydostania się z niewoli analogii mącą nastrój zbudowany przez nagromadzenie elegijnych porównań, wytwarzając charakterystyczny dla romantycznej świadomości splot rozczarowania i buntu, kontrast niepozbawiony ironicznego posmaku.

O tym, że postawa romantyczna nie była wolna od ambiwalencji, przekonuje Zwiędła róża, późny tekst Lenartowicza napisany po śmierci przyjaciółki, Krystyny Dybowskiej. Wiersz, utrzymany w tonie elegijnego wspomnienia, posługuje się pozbawiającą złudzeń metaforą kruchości pamięci („Szlak się srebrzysty ciągnie za łódką:/ To nasza pamięć...”), która jednak ma dość siły, by kilka wersów dalej zmaterializować przeszłość. „Otóż my razem" - oznajmia podmiot, po czym rozwija wspomnienie tak boleśnie intensywne, że poetycki cud jakby się wydarza. Magii dostarcza prozopopeja, która pozwala odpowiedzieć zmarłej na czułe pytania opłakującego. On pyta: „Czy ci wygodnie? Pozwól poprawię/ Twoje wezgłowie puchowe”. Ona odpowiada: „Połóż 
tu rękę pod moją głowę/ I mów, mów dalej: ja słucham ciebie". Zadziwiająca replika odebrałaby mowę, gdyby nie jej znaczące odwleczenie. Odpowiedź pada dopiero po kilkudziesięciu wersach, wśród których znajduje się fragment o ogrodzie ze „znajomych stron”, sprawiedliwie rozbrajający iluzję:

Roślinność taką wydają chłody,

Nie życie - zimny ślad życia.

Z tych kwiatów z mrozu, bracie, niestety,

Umarłym wiązać bukiety.

Opis włożony między kwestie dialogu sygnalizuje liryczną konwencjonalność rozmowy żywych z umarłymi, którą umożliwia „nie życie” - jak napomina wiersz - lecz „zimny ślad życia”, czyli poetycki tropizm (prozopopeja). W Zwiędtej róży sumienie żywego ostatecznie przystaje na nieuniknione pośrednictwo śladu (tropu) w rozmowie z „różą z przedwczora”. Stąd łagodna perswazja: „Odpocznij, proszę; o tęczy złotej/ Wspominać będziem już bez tęsknoty [...]". W tym iście wordsworthowskim finale Lenartowicz łączy pamięć z wyobraźnią, wybierając trzecią drogę - pogodzone z rzeczywistością wspomnienie krzyżuje $\mathrm{z}$ rozpoznawalnym romantycznym gestem kreacyjnym, spinającym przeszłość i teraźniejszość łukiem niemożliwej złotej tęczy.

\section{Zatarty ślad. Zwiędly listek Adama Asnyka ${ }^{24}$}

Śladem romantyków podążał Adam Asnyk, tęskniąc - jak pisze Kuczera-Chachulska - „do duchowej atmosfery cudu”. Badaczka zauważa, że poeta, „kontemplujący rozpoznania poetów wcześniejszych, przetwarzający je na stabilny kształt pojęć i esencjalizujące konstrukcje wierszowe”, dokonuje „klasycyzacji osiągnięć romantycznych" ${ }^{25}$. Ten kodyfikujący temperament Asnyka z krytycyzmem opisuje Zofia Mocarska-Tycowa. Różnorodne motywy „ulegają kostnieniu i redukcji, kurcząc się do dość jałowych schematów”, zachodzi „proces petryfikacji i wyjałowienia stałych i odwiecznych obrazów-idei”" ${ }^{26}$. Kostnienie, redukcja, kurczenie, jałowienie, petryfikacja (które w bardziej

${ }_{24}$ Tekst Zwiędtego listka zamieszczam $\mathrm{w}$ aneksie. Ten $\mathrm{i}$ inne wiersze poety cytuję za wydaniem: A. Asnyk, Poezye, t. 1-3, Warszawa 1898.

25 B. Kuczera-Chachulska, op.cit., s. 260.

${ }^{26}$ Z. Mocarska-Tycowa, Wyboryi konieczność. Poezja Adama Asnyka wobec gustów estetycznych i najważniejszych pytań swoich czasów, Toruń 1990, s. 33. 
przychylnym języku drugiej autorki nazywane są stabilizacją, klasycyzacją, esencjalizacją) dają sugestywne wyobrażenie „starej" poezji zastygającej w konwencji. Asnyk działał przy tym „z pozycji mędrca” - „nie chce czuć”, ale „mimo wszystko wie" ${ }^{27}$. Zdolność do krystalizacji w wystudiowanej formie pozauczuciowej jest, paradoksalnie, bardzo własną i fascynującą cechą warsztatu autora Sonetów nad głębiami. Zamieranie, które wydarza się pod piórem poety łaknącego cudu, zawiera w sobie nietypowy potencjał elegijny: każdy spetryfikowany wiersz przeczytać można jako elegię na odejście czucia z formy. Miłosne wyznanie bez żaru, potęga natury bez lęku, wspomnienie dzieciństwa bez ściśniętego gardła?

Portret kamienny liryki Asnyka (na użytek wywodu nieco przerysowany) odkrywa przed współczesnym czytelnikiem niespodziewane powaby. Postaram się je opisać na przykładzie Zwiędtego listka, mistrzowskiego tekstu, który w ramach tak zdefiniowanej problematyki może pełnić funkcję poetyckiego credo. W utworze, stanowiącym jedną z licznych miniatur wykorzystujących motyw kwiatów, obraz więdnięcia tradycyjnie wspiera wymowę uniwersalnych prawd o oddaleniu i przemijaniu, które jednak tym razem nie wiążą się z losem wygnańca, lecz zakochanego. Miłość do Anieli Grudzińskiej, uwikłana w konwenans (a zatem spetryfikowaną formę) i zakończona odrzuceniem listownych oświadczyn, wyznacza kontekst biograficzny wiersza. Nieprzeciętny urok drobnego utworu doceniła Mocarska-Tycowa, interpretując go jako świadectwo „kruchości piękna i bezowocności ludzkiego usiłowania, by dać odpowiedni wyraz wzruszeniu” ${ }^{28}$. Zwiędly listek o próbie „dawania wyrazu” mówi zupełnie wprost, dlatego może być odczytywany jako wiersz autotematyczny.

Poeta powierza pismu thumione dotąd nadzieję i smutek (wszystko „com marzył i com czuł”), przenosząc funkcję listu na liść białej róży. Biel kojarzy się z gotowością czystej kartki papieru, chociaż powiązanie takie nie ma prostego uzasadnienia (liść białej róży nie jest przecież biały!). Wiersz jednak z zachwycającą siłą narzuca to skojarzenie, wymuszając na czytelniku metonimiczne przeniesienie znaczenia bieli z kwiatu na liść. Sugestia jest tak wyraźna, że Mocarska-Tycowa omawia wiersz przekonana, że zapisuje się on na „białym płatku”, nie liściu, dokonując bardzo wymownego błędnego odczytania. Miłosne wyznanie ma już zostać wysłane, wraz z prośbą o odpowiedź utrwaloną w ten

\footnotetext{
27 B. Kuczera-Chachulska, op.cit., s. 255.

${ }_{28}$ Z. Mocarska-Tycowa, op.cit, s. 61.
} 
sam sposób, mimo to $\mathrm{z}$ jakiegoś powodu autor postanawia sam odczytać swoje dzieło:

\section{Lecz kiedy me wyrazy}

Chciałem odczytać znów,

Dojrzałem w listku skazy,

Nie mogłem dostrzec słów.

I pożółkł listek wiotki,

Zatarł się marzeń ślad,

I zniknął wyraz słodki,

Com jej chciał posłać w świat!

Dziwny jest bieg czasu w tym wierszu. Ile go upłynęło między opisanymi wydarzeniami? Co właściwie zaszło w przerwie odzielającej pisanie od czytania? Dlaczego poeta powrócił do gotowego już listu? Czy z zamiarem wprowadzenia korekty? Jak bardzo odwleczonej? A może celem było przypomnienie, przywołanie dawno już powiędłych snów, nadziei, marzeń i smutków? Jakby poeta zapomniał, co sam napisał, albo nawet - co czuł, jakby bawił się „efektem inskrypcji”, pozwalającym przyglądać się własnemu pismu, w którym rozpoznaje się kogoś innego, dawno już nieobecnego, „onego” (czyli „postać, jaką przez ślad uzyskuje nieodwracalna przeszłość” ${ }^{29}$ ). Chociaż wiadomo, że minęło w wierszu wystarczająco dużo czasu, by uczucia pożółkły, zatarły się i ostatecznie zniknęły, to przecież nie wiadomo, ile go upłynęło. Elegijny smutek zawiera się w tym niezwerbalizowanym, zjawiającym się bezgłośnie temporalnym rozsunięciu, między niemożnością utajenia („Nie mogłem taić dłużej”) a niemożnością ujawnienia („Nie mogłem dostrzec słów”). Spośród omówionych wierszy to Zwiędty listek najdobitniej ujmuje paradoks śladu: „niesłyszalna różnica między zjawiającym się a zjawianiem (między światem a przeżyciem) jest warunkiem wszelkich innych różnic, wszelkich innych śladów i sama jest już śladem" ${ }^{\circ}$. Mimo że Asnyk opisuje wtórną różnicę między przeżyciem a przedstawieniem oraz czyni ją głównym zadaniem autotematycznego namysłu, to przecież również ta pierwsza, niesłyszalna i niewyrażalna, jest milczącą (z konieczności) bohaterką liryku.

Poeta chciałby „uciec z duszą na listek”, ale nie może. Wiersz obrazuje fiasko paralelizmu człowieka i natury jako idei „odpo-

\footnotetext{
29 E. Lévinas, op.cit., s. 225.

$3^{\circ}$ J. Derrida, op.cit., s. 98.
} 
wiedniości” i „łączności”, romantyczna poczta, będąca „rezultatem siły poetyckiego przeżywania”, zawodzi Asnyka. Uczuć nie da się uobecnić przez przepisanie. Korespondencja jako $p a-$ rousia byłaby sprzecznością, „dzikim śladem” - przemijaniem i zjawianiem się jednocześnie. Poczta jest zawodna. Rozmaite technologiczne eksperymenty romantyków, którzy chcieli otrzymywać ją natychmiast, teraz, bez nieuniknionego opóźnienia wpisanego w naturę listu jako śladu, bywały przekorne, naznaczone przeczuciem klęski. Wszakże bezokolicznikowa przypadłość projektów lozańskich jest właśnie ich „skazą” (zamierzam uciec, ale - czy zdołam?). Z kolei w Królu zamczyska Seweryna Goszczyńskiego (podobnie zresztą jak w IV części Dziadów Mickiewicza) na ten sam przedmiot patrzą szaleniec i sceptyk: pierwszy widzi list, drugi - jedynie liść; pierwszy prowadzi symboliczną correspondance, drugi nie potrafi na nią adekwatnie odpowiedzieć.

Zwiędly listek, odczytywany jako tekst autotematyczny (kamienny autoportret Asnyka), odsyła do podwójnej znaczeniowości zapominania, które wynika - posłużę się formułami Mocarskiej-Tycowej - zarówno z konieczności, jak i z wyboru. Zapominanie pojmowane jako zanik śladu („zatarł się marzeń ślad") jest nieuniknione. Zatarcie to uniwersalny trop czasowości: odsyła do utraty pamięci, starzenia się, śmierci, a jednocześnie jest tropem tropizmu jako takiego ${ }^{3}{ }^{\text {I }}$. Możemy zatem wyczytać z tekstu Asnyka prawdę o przemijaniu, ulotności i niewyrażalności uczuć, ale - z drugiej strony - również coś o zużyciu afektowanej konwencji tropologicznej, o atrofii wiary w uobecniającą moc języka poezji. Otwiera się możliwość umieszczenia niektórych „spetryfikowanych” wierszy poety w nurcie swoistej art oblivionis, o której pisze Ricoeur: „sztuka zapominania musiałaby się opierać na retoryce zaniku: pisać, by zniknaćc" ${ }^{32}$. Retoryka zaniku - tak ostentacyjna w Zwiędhym listku - rozpatrywana jest przez filozofa między innymi w kontekście traumy. Dla poety „ogłuszonego rezonansem romantycznym" ${ }^{33}$ stanowi formę higieny pamięci, umożliwia pisanie za

${ }^{3}$ Metaforą zacierania posłużył się Friedrich Nietzsche, definiując tropologiczną naturę prawdy: „prawdy są złudami, o których zapomniano, że nimi są, metaforami, które się zużyły i utraciły zmysłową siłę wyrazu, monetami, których powierzchnia się starła i które teraz są traktowane jako metal, już nie jak monety”. F. Nietzsche, O prawdzie i ktamstwie w pozamoralnym sensie, przeł. B. Baran, w: Pisma pozostałe, Kraków 2004, s. 164.

$3^{2}$ P. Ricoeur, Pamięć. Historia. Zapomnienie, przeł. J. Margański, Kraków 2006, s. 664.

33 B. Kuczera-Chachulska, op.cit., s. 255. 
cenę pozostawienia w jej odwodzie „najsłodszych serca snów”. Zapominanie staje się techniką. Polega ona na wykorzystaniu oddalającego potencjału śladu, a w praktyce poetyckiej przejawia się mozolną pracą zamienni. W omawianym wierszu uczucia wędrują ze snów do słów ( $\mathrm{z}$ „najsłodszych serca snów” do „słów, co w piersiach drżały”), które następnie odciskają się na „listku róży białej”. Listek jest z kolei ekwiwalentem listu, wyrazistym dzięki skojarzeniu, przenoszącemu biel od kwiatu do liścia, od liścia do czystej kartki papieru. To metonimiczne śladowanie, zdolność do budowania - jak to ujmuje Mocarska-Tycowa „spiętrzonych zamienni”, wywołuje efekt wielostopniowego zapośredniczenia przeżyć.

Badaczka uważnie obserwuje ten proces: „schematyczne ciągi leksykalne” służą „unifomizacji wypowiedzi” poetyckiej, umożliwiają szerokiej rzeszy czytelników „napełnianie jej stosownymi wzruszeniami" 34 . Również Tadeusz Budrewicz zauważa, że poeta preferuje bezwysiłkowe metafory „bliskie doświadczeniu językowemu przeciętnego czytelnika” ${ }^{35}$. Asnyka „etiudy metonimiczne" ${ }^{6}$ kojarzą mi się z formalistyczną, klasycystyczną gimnastyką w Mickiewiczowskiej Zimie miejskiej, którą tak oto puentował Dariusz Seweryn: „leksykalno-składniowo- erudycyjna kombinatoryka klasycyzmu potrafi doskonale rozwijać swój ornament również w myślowej próżni” 37 . Czyż Asnyk, posługując się zbliżoną metodą, nie dowiódł w Zwiędhym listku, że „kombinatoryka romantyczna” zadziała w „próżni uczuciowej”? Że można się nią posłużyć, nie obiecując sobie zbyt wiele, nie dając się zwodzić dzikiemu śladowi i złotej tęczy?

Oczywiście, ten dialog tradycji pełen jest niuansów i niejasności wynikających z faktu, że - po pierwsze - postawa romantyczna cechowała się ambiwalencją, po drugie - stosunek Asnyka do tej ambiwalencji również był ambiwalentny. Niezwykle „chytrą” i „sprytną”, powiedziałaby Agata Bielik-Robson, odpowiedzią romantyków na stratę rozpoznaną w jesiennym paralelizmie (różnica wpisana $\mathrm{w}$ analogię prowadzi do myśli o oddaleniu, nieodpowiedniości, wyobcowaniu, zaniku itp.) był postulat przekornego rozpinania tęczowych (poetyckich) mostów.

34 Z. Mocarska-Tycowa, op.cit., s. 29.

35 T. Budrewicz, „Świeża poezja” gór, w: Wiersze pozytywistów. Interpretacje, Katowice 2000, s. 57.

${ }^{36}$ Określenie Wacława Borowego cytuję za: C. Zgorzelski, Wstęp, w: A. Mickiewicz, Wybór poezyj, t. 1, oprac. C. Zgorzelski, Wrocław 1986, s. XI.

37 D. Seweryn, Zimowe gry literackie, w: „...jak tam zaszedtes”. Mickiewicz w szkole klasycznej, Lublin 1997, s. 29. 
Poetom nie chodzi jednak o okłamywanie samych siebie, ale o kompromis: „uczestnicząc w ruchu detronizowania tradycji, jednocześnie stawiają oni opór ulatnianiu się wszystkiego, co stałe” ${ }^{8}$. Chociaż John Keats twierdził, że Izaak Newton „zniweczył całą poezję tęczy, redukując ją do barw załamanych w pryzmacie" ${ }^{39}$, to przecież inni twórcy epoki (a nawet sam Keats) nie przejmowali się tym ponad miarę. Lenartowicza nietęskne wspominanie „tęczy złotej” to sprawdzona poetycka replika na rozczarowanie. W wielu wierszach Asnyka dostrzegamy równie dwuznaczny stosunek do tradycji, z tym że poeta, nie mogąc się już mierzyć wprost z romantycznym problemem „tęczy Newtona”, podejmuje inne wyzwanie - „romantycznej tęczy Newtona". Z nią między innymi dyskutuje programowy wiersz $D o$ młodych. Jakkolwiek „tęcza idealnych snów”, będąca w tekście dość czytelną figurą omówionej tradycji, nieodwołalnie „zachodzi w ciemność”, to odnalezienie kolejnego kompromisu, „prawdziwej mądrości” jest niezbędne, by i z tęczą, i z resztą niknącego świata mimo wszystko się pogodzić. Myśli tej, skierowanej do młodych, Asnyk pozostał wierny, gdy na kilka lat przed własną śmiercią z szacunkiem przemawiał nad trumną Lenartowicza - poety, który jako jeden z nielicznych zdołał ,podsłuchać wszystkie tęskne szumy naszych wierzb i brzóz płaczących”, którego pieśni płynęły odgłosami „cichego łkania sieroty i przytłumionej skargi" ${ }^{\circ}$.

\section{Stefan Garczyński, Odpowiedź na list}

Czyż od drzewa w jesieni zdjęty liść samotny,

Sierota, uniesiony ręką dzikiej burzy,

Szczęśliwym zwać się może, kiedy wiatrom służy? -

Wzbije się czasem w górę - dla czego? bo lotny,

Bo go nic nad przypadek ni wzbije, ni zniży.

Ale popłyń choć chwilę dzikim jego śladem,

Przypatrz mu się dokładniej i rozpatrz się bliżej,

Zżółkłym ci w oczach stanie, otoczony gadem,

Który go wskroś przekąsił i wciąż go przekąsa.

$3^{8}$ A. Bielik-Robson, Racjonalność romantyzmu, w: Romantyzm i nowoczesność, red. M. Kuziak, Kraków 2009, s. 60.

39 Zob. M.H. Abrams, Zwierciadło $i$ lampa. Romantyczna teoria poezji a tradycja krytycznoliteracka, przeł. M.B. Fedewicz, Gdańsk 2003, s. 337, 339.

40 A. Asnyk, [Przemówienie nad trumna Lenartowicza], w: Gtosy o Lenartowiczu, wybór, oprac. P. Hertz, Kraków 1976, s. 270. 
Tobie droga! Kwiatkami nadzieja potrząsa

Lata młode - dla tego pozostaw jesieni,

Wiatrom chłodnym i burzy listek pożółciały.

One go swą przemocą od matki porwały,

Wiatr go i dzisiaj dalej w powietrzu pierścieni.

Daj mu płynąć - daleko niebożę popłynie;

Ale wierzaj - wkrótce zginie!

Teofil Lenartowicz, Liście zwiędte

I

I pod cieńmi moimi pielgrzym odpoczywał, I pod cieńmi moimi słowik w nocy spiéwał, I wielbiciel piękności świeżość moją chwalił, I dziewczę, że jej promień słońca nie opalił, I pastuch, że go deszcze nie zmoczyły letnie; I ja, widzicie; żyłem pięknie i szlachetnie. A dziś, kiedy mi dano tyle się natrudzić, Spadam zasnąć tak dobrze, żeby się nie zbudzić. Przechodniu, jeśli tobie los mój coś poszepce, Niech mnie twa dobra stopa na drodze nie depce.

II

Liściu mój suchy,

Liściu mój kruchy,

Co mi tak spadasz pod nogę,

Odwiany z krzaku

Żółty biedaku

Ja ciebie deptać nie mogę.

Bo i ja zwiany

Z Polski kochanej,

I ja bez żadnej opieki;

I mną po piasku

W tych dniach bez blasku

Podrzuca losu wiatr lekki.

I moja cała

Dusza zwiędniała,

I młode odbiegło życie;

I jak ty, bracie,

Po wiosny stracie

Przeznaczon jestem na gnicie. 
Więc na mej drodze

Ja cię obchodzę,

$\mathrm{W}$ głuchą idący dolinę;

I wszystkie bratnie

Liście ostatnie

Z ściśniętym sercem ominę.

III

Choć ja nie jestem zielony,

Lecz i nie jestem zgubiony,

$\mathrm{O}$, bracie mój!

Choć cię od słońca nie grodzę,

Choć cię od żaru nie chłodzę,

Gdzie szemrze zdrój.

Świetna ozdoba ogrodu,

Gdy była potrzeba chłodu,

Jam chłody niósł;

Gdy było liści potrzeba,

Jam się wyciągnął do nieba

I rósł a rósł.

Dziś, kiedy słońce nie pali,

A śniegi ciągną z oddali

Ku naszej drogiej ojczyźnie,

Jak kiedyś cienie dawałem,

Tak dzisiaj ziemię mym ciałem

Użyźnię...

IV

Dmiéj, wietrze, dmiéj,

Siecz, burzo, siecz!

Wiedząc, w czym rzecz,

Serce, się śmiéj.

Z mogity, bacz,

Na radość strzech

Wyrasta śmiech

Głuszący płacz.

I życia pień

Przez wieków ciąg

Otacza w krąg

Miłości bluszcz... 
Adam Asnyk, Zwiędly listek

Nie mogłem tłumić dłużéj

Najsłodszych serca snów:

$\mathrm{Na}$ listku białej róży

Skreśliłem kilka słów.

Słowa, co w piersiach drżały

Nie wymówione w głos,

$\mathrm{Na}$ listku róży białéj

Rzuciłem tak - na los!

Nadzieję, którąm pieścił, I smutek, co mnie truł, I wszystkom to umieścił, Com marzył i com czuł.

Tę cichą serca spowiedź Miałem jej posłać już I prosić o odpowiedź Na listku białych róż...

Lecz kiedy me wyrazy Chciałem odczytać znów, Dojrzałem w listku skazy, Nie mogłem dostrzedz słów.

I pożółkł listek wiotki, Zatarł się marzeń ślad, I zniknął wyraz słodki, Com jej chciał posłać w świat!

\section{WOJCIECH HAMERSKI}

\section{Three withered leaves, three sad poems (Garczyński, Lenartowicz, Asnyk)}

This text provides an interpretation of three poems, written by nineteenth century poets, that share a common theme of Autumn, with a particular attention given to the motif of a withered leaf. The author is interested how the poems in question match the elegiac convention of autumn lyric poetry and, at the same time, how each in its own way tries to overcome this convention. In Odpowiedź na list written by Stefan Garczyński, the acceptance of passing is concurrently met with defiance, expressed in a language of paradoxical metaphor. Teofil 
Lenartowicz in his Liście zwiędte breaches the formal elegiac tone with the application of underlying vitalistic overtones included in the poem. Adam Asnyk's Zwiędly listek, through a superposition of metonymies, achieves the effect of multilayered mediation and erasure of the trace of experience. The reading and understanding of the three poems, composed in Romanticism and post-Romanticism periods, make it possible to observe, fragmentarily of course, the multiplicity of different poetic attitudes that accompany the process of re-enchantment of the world.

Key words: Stefan Garczyński, Teofil Lenartowicz, Adam Asnyk, elegy, subjectivity, the theme of Autumn.

WOJCIECH HAMERSKI - doktor, adiunkt w Zakładzie Literatury Romantyzmu Instytutu Filologii Polskiej UAM. Zajmuje się literaturą dziewiętnastowieczną, obecnie pracuje nad zagadnieniami ironii romantycznej i jej recepcją we współczesnej refleksji humanistycznej. Autor książki Romantyczna troposfera powieści. Interpretacje prozy Kraszeweskiego, Sztyrmera i Kerzeniowskiego (2010). Redaktor tomów zbiorowych, np. Siła komentarza. Romantyzmy literaturoznawców (2011), autor artykułów i recenzji publikowanych m.in. w „Zeszytach Karmelitańskich”, „Pamiętniku Literackim”, „Czasie Kultury”, „Przewodniku Bibliograficzno-Metodycznym”. Redaktor serwisu sztukapilki.pl, wespół z Jerzym Borowczykiem przygotowuje antologię literatury piłkarskiej, której publikację zaplanowano na rok 2012. e-mail: vothjak@amu.edu.pl 
